\title{
Introduction
}

\author{
Nathan Jun ${ }^{1}$
}

[Article copies available for a fee from The Transformative Studies Institute. E-mail address: journal@transformativestudies.org Website: http://www.transformativestudies.org (C2012 by The Transformative Studies Institute. All rights reserved.]

To those who were unable to attend the Third Annual Conference of the North American Anarchist Studies Network this past January in San Juan, Puerto Rico, let me take this opportunity to express my sincere condolences. To say you missed out would be an understatement of North American (not Caribbean, I hasten to add!) proportions.

Compared to its predecessors, NAASN $-3^{2}$ was a much more relaxed and intimate affair than its predecessors, which is perhaps appropriate enough for an anarchist gathering on a tropical island. True, it was not nearly as well-attended as the spectacular 2009-10 inaugural in Hartford, let alone the larger-than-life anarcho-extravaganza that was NAASN-2 (2011-2012) in Toronto, but what NAASN-3 lacked in quantity it more than made up for in prolific je ne sais quoi (or should I say no se que?). With the exception of a few familiar faces-from the elder statesmen (Dana Ward, Allan Antliff, Jon Bekken), to the stalwarts (Jesse Cohn, Andrew Hoyt, Michael Loadenthal, Ed Avery-Natale, James Birmingham), to the diplomats from abroad (Alex Prichard)- the attendees were overwhelming Puerto Rican (with a random Swiss thrown in here and there for good measure! $\left.{ }^{3}\right)$. This was true not only of the presenters and conference organizers, but also of the people in the audience - many of whom, by all reasonable appearances, were neither anarchists nor even radicals, but simply ordinary Puerto Ricans who had

\footnotetext{
${ }^{1}$ Nathan Jun, Ph.D., is Assistant Professor of Philosophy at Midwestern State University. Address correspondence to: Dr. Nathan Jun, Midwestern State University, 3410 Taft Boulevard, Wichita Falls, TX 76308, USA; tel: 940-397-4128; e-mail: nathan.jun@mwsu.edu.

${ }^{2}$ For more information on the conference, including a list of presentations, see http://naasnpr.org/

${ }^{3}$ I.e., Nino Kühnis, author of " WWe' is for Anarchism: Construction and Use of Collective Identity in the Anarchist Press of Fin-de-siècle Switzerland," in this issue.
} 


\section{Nathan Jun}

come to listen to the presentations and educate themselves about anarchism. I can honestly say I have never attended an anarchist event before or since where even a sizeable minority of the participants were non-anarchists driven by simple curiosity or an honest desire to learn.

Most impressive of all is that such a remarkable event was planned, promoted, and staged with limited prior connection to the stateside network in a geographically isolated environment without a significant anarchist movement. Here all credit is due to the conference organizers, who, I have since come to believe, are among the most impressive comrades I have ever had the pleasure of meeting in my anarchist life. ${ }^{4}$ I remain in awe of their incredible determination and professionalism, to say nothing of the warmth, hospitality, and friendliness with which they welcomed all and sundry to their beautiful island home. NAASN-3 marked the beginning of a long overdue Puerto Rican anarchist resurgimiento which has been growing steadily and unabated since January with new projects and initiatives being developed even as I write. $^{5}$

Although this special issue of Theory in Action provides a solid sample of the range of topics that were discussed at NAASN-3, I will be the first to admit - and I'm sure my co-editor would agree- that it drastically fails to capture the authentic spirit of the event, a task which would be difficult even under the best of circumstances. NAASN-3 was bilingual, like Puerto Rico and North America more generally. Presentations were delivered in both Spanish and English; gifted and extremely hard-working volunteers provided translations in real-time to monolingual attendees in the rear of the conference venue. Because Theory in Action is an English-language publication, and because very few of the Spanish-speaking participants were able to translate their presentations into English for inclusion in this issue, most of the articles contained herein represent, at best, a small cross-section of the Anglophone presentations. This is lamentable, as the Spanish-language presentations spoke most directly to the distinctive concerns of Caribbean peoples in general and Puerto Rican people in particular. If anything, this makes Fernando Janer's essay on education and Jorell

\footnotetext{
${ }^{4}$ For more on the planning and preparation of NAASN-3, see Daniel Cairns, "An Interview with the Comité Organizador de la 3ra Conferencia Anual de la NAASN, Puerto Rico,", http://libcom.org/library/interview-comit\%C3\%A9-organizador-de-la-3raconferencia-anual-de-la-naasn-puerto-rico.

${ }^{5}$ See http://naasnpr.org for information about the Puerto Rican anarchist movement's progress over the course of the past 6 months, including the development of Infoshop Santurce in San Juan.
} 
Meléndez' article on the history of Puerto Rican anarchism all the more significant and valuable.

In his epilogue 6 , my comrade and co-editor Michael Loadenthal reprises a topic I addressed in my guest editorial last year-namely, the often contentious relationship between activists and scholars. There is no doubt in my mind that Michael was moved to write this article in part because of our experiences in San Juan in January, which powerfully belied the notion that anarchist studies is an elite domain occupied exclusively by privileged, disengaged pedants. It is one thing to argue in favor of bridging the chasms between theory and practice, intellectual work and activist work, etc., as anarchist scholars are keen to do; it is another thing entirely to have a lived experience of this bridging-to physically, mentally, emotionally, and psychologically encounter the overcoming of these seemingly intransigent dichotomies. NAASN-3 proved decisively that anarchist studies just is a form of activism, one that has a profound capacity to engage non-anarchists and inspire the oppressed. The challenge of every anarchist group, whatever its form of activism, should be to emulate this amazing achievement-drawing in workers, elderly men and women, people of color, the differently-abled, etc. and meeting them where they are in a spirit of mutual respect and reciprocal recognition.

I think there is good reason to believe this challenge will be met. It is not an exaggeration to say that we are entering a golden age of anarchist studies, as evidenced by the sheer quantity of anarchist studies organizations, events, and projects currently on offer. In September 2012, the Anarchist Studies Network (UK) will host its second international gathering in Loughborough, followed shortly thereafter by the fourth NAASN conference in New Orleans, LA. The anarchist studies milieu has been creating, or actively contributing to, journals (Anarchist Studies ${ }^{7}$, Anarchist Developments in Cultural Studies ${ }^{8}$, Theory in Action ${ }^{9}$ ); publishing and distributing ventures (AK Press ${ }^{10}$, PM Press ${ }^{11}$, Arissa Media Group ${ }^{12}$, Little Black Cart ${ }^{13}$, Corvus Distribution $\left.{ }^{14}\right)$; book

\footnotetext{
${ }^{6}$ See his "Anarchism \& Academia, Insurrection \& Illegality: Age Old Tensions Revisited" in this issue.

${ }^{7} \mathrm{http}: / /$ www.lwbooks.co.uk/journals/anarchiststudies/contents.html

8 http://www.anarchist-developments.org/

9 http://www.transformativestudies.org/publications/theory-in-action-the-journal-of-tsi/

${ }^{10} \mathrm{http}: / /$ www.akpress.org/

11 http://pmpress.org/

$12 \mathrm{http}: / /$ arissamediagroup.wordpress.com/

${ }^{13} \mathrm{http}: / /$ littleblackcart.com/

${ }^{14}$ http://www.corvusdistribution.org/
} 


\section{Nathan Jun}

series (Contemporary Anarchist Studies ${ }^{15}$, Anarchist Interventions ${ }^{16}$ ), schools, institute, and organizations $\left(\mathrm{NAASN}^{17}, \mathrm{ASN}^{18}\right.$, Institute for Anarchist Studies ${ }^{19}$, Anarchist Studies Initiative ${ }^{20}$, Transformative Studies Institute ${ }^{21}$, Corvid College ${ }^{22}$ ); media projects (Submedia ${ }^{23}$, The Horizontal Power Hour ${ }^{24}$, Capitalism is the Crisis ${ }^{25}$, Anarchism: A Documentary ${ }^{26}$ ); and libraries and archives (The Anarchist Library ${ }^{27}$, The Anarchy Archives ${ }^{28}$, The Kate Sharpley Library ${ }^{29}$, The Libertarian Labyrinth $^{30}$ ). NAASN members, to say nothing of anarchist studies scholars abroad, are making important contributions in virtually every field of inquiry, including, but not limited to, sociology (Dana Williams, Jeff Shantz, Deric Shannon, Abbey Williams, Ed Avery-Natale, Andrej Grubacic, etc.), literary and cultural studies (Michael Truscello, Jesse Cohn, Sandra Jeppesen, Caroline Kaltefleiter, etc.), history (Maia Ramnath, James Scott, Steven Hirsch, Tom Goyens, Kirwin Shaffer, Raymond Craib, Hillary Gordon, Barry Pateman, Robert Graham, Andrew Hoyt, Andy Cornell, Mark Leier, Davide Turcato, Shawn Wilbur, Kenyon Zimmer), political theory (Kathy Ferguson, John Clark, Todd May, Jason Adams, Duane Rousselle, Michael Loadenthal). To this growing list, I am pleased to say, we can now add various Puerto Rican comrades, including Jorell Meléndez Badillo and Fernando Janer.

A final thought: In the wake of every NAASN conference to date, police have been summoned and comrades from foreign countries have been detained by border agents and prevented from reaching their destination. During a plenary session at NAASN-3, this fact was offered up as evidence that our enemies, at least, regard anarchist scholars and intellectual workers as a serious threat worthy of being intimidated, surveilled, and harassed. If our enemies take us seriously, why, so often,

\footnotetext{
${ }^{15} \mathrm{http}: / /$ www.continuumbooks.com/series/detail.aspx?SeriesId $=2244$

$16 \mathrm{http}: / /$ www.anarchiststudies.org/ias-akbooks

${ }_{17}$ http://naasn.org

18 http://anarchist-studies-network.org.uk/

19 http://www.anarchiststudies.org/

${ }^{20} \mathrm{http}: / / \mathrm{www} 2$. cortland.edu/centers/CGIS/asi/index.dot

21 http://www.transformativestudies.org/

22 http://corvidcollege.wikidot.com/

23 http://submedia.tv/

${ }^{24} \mathrm{https://horizontalpowerhour.wordpress.com/}$

$25 \mathrm{http}: / /$ capitalismisthecrisis.net/

${ }^{26} \mathrm{http}: / /$ anarchismdocumentary.net/

${ }^{27} \mathrm{http} / / /$ theanarchistlibrary.org/

${ }^{28} \mathrm{http}: / /$ dwardmac.pitzer.edu/Anarchist Archives/

${ }^{29} \mathrm{http}$ ://www.katesharpleylibrary.net/

30 http://libertarian-labyrinth.org/archive/Welcome
} 
do our friends dismiss us-especially when we are proving, time and again, to be such skilled torchbearers in the cause of anarchism?

For more information on the North American Anarchist Studies Network, see http://naasn.org. 